\title{
Effect of Ni Doping on Ce-Mg-O Nanosize Catalysts for CO Oxidation
}

\author{
Nurak GRISDANURAK ${ }^{1,2}$, Yupin PHUPHUAK ${ }^{1}$, \\ Jatuporn WITTAYAKUN ${ }^{3}$ and Keisuke FUKAYA ${ }^{4}$ \\ ${ }^{1}$ Department of Chemical Engineering, Faculty of Engineering, \\ Thammasat University, Pathumthani 12120, Thailand \\ ${ }^{2}$ NCE-EHWM, Thammasat University, Pathumthani 12120, Thailand \\ ${ }^{3}$ School of Chemistry, Suranaree University of Technology, \\ Nakorn Rachasrima 30000, Thailand \\ ${ }^{4}$ National Nanotechnology Center, NSTDA, \\ Pathumthani 12120, Thailand
}

Keywords: Nanoparticle, $\mathrm{CeMgO}, \mathrm{CO}$ Oxidation

\begin{abstract}
Material of CeMg mixed oxide nanoparticle doping with Ni metal can be applied as catalyst for CO oxidation reaction. It was successfully synthesized by macromolecule surfactant modified method and characterized by XRD, BET, and TEM-EDX techniques. Both alkaline-earth $\left(\mathrm{Mg}^{2+}\right)$ and transition metal $\left(\mathrm{Ni}^{2+}\right)$ doped into $\mathrm{CeO}_{2}$ entered the lattice of $\mathrm{CeO}_{2}$ to form a solid solution of $\mathrm{CeMgO}$ and $\mathrm{CeMgNiO}$, respectively. $\mathrm{Ni}$ doping on CeMg mixed oxide showed much better activity of $\mathrm{CO}$ oxidation compared to $\mathrm{CeMg}$ mixed oxide itself.
\end{abstract}

\section{Introduction}

Carbon monoxide $(\mathrm{CO})$ is one of green house gases, mostly contributed from vehicle exhaust. CO can maintain in the troposphere about 3 years; therefore many researches make more effort to reduce its concentration. $\mathrm{CO}$ oxidation and selective oxidation are promising solution to reduce the concentration before emission. The supported noble metals ( $\mathrm{Au}, \mathrm{Pt}, \mathrm{Pd}$ and $\mathrm{Ir}$ ) have been widely used for CO oxidation (Ma et al., 2007; Zhu et al., 2007). However, supported noble metals, although very active, are not fully satisfactory, due to their high price and scarce resource. In the past few years, a great deal of attentions has been focused on cerium-based materials for used in automotive exhaust catalysts in order to reduce CO concentration (Kasaepar et al., 1999; Boaro et $a l ., 2003)$. Ceria $\left(\mathrm{CeO}_{2}\right)$ has been widely used as a promoter and an oxidation catalyst because of its unique redox properties and high oxygen storage capacity (Costa $e t$ al., 2003). To gain more effective activity, catalyst structure requires being in nanoparticles (Chen et al., 2005a).

Additions of dopants (such as $\mathrm{Zr}, \mathrm{Ti}, \mathrm{Mg}$, etc.) into $\mathrm{Ce}$ have been gained attention for oxidation processes (Terrbile et al., 1998; Zhang et al., 2006; Li et al., 2007; Romero-Sarria et al., 2008). They induced catalysts highly uniform nanosize particles, improving its stability and activity. The activity of catalyst was found

Received on July 12, 2008; accepted on May 28, 2009. Correspondence concerning this article should be addressed to N. Grisdanurak (E-mail address: gnurak @engr.tu.ac.th).

Presented at ISCRE 20 in Kyoto, September, 2008. to be dependent on the Ce/dopant ratio. For example, $\mathrm{Ce}_{0.75} \mathrm{Zr}_{0.25} \mathrm{O}_{2}$ exhibited the highest activity in $\mathrm{CO}$ oxidation (Over and Muhler, 2003). As well, $\mathrm{Ce}-\mathrm{Mg}-\mathrm{O}$ new material showed excellent work in methane combustion. The activities of series of $\mathrm{Ce}-\mathrm{Mg}-\mathrm{O}$ samples were much higher than $\mathrm{CeO}_{2}$ and $\mathrm{MgO} . \mathrm{Ce}_{0.9} \mathrm{Mg}_{0.1} \mathrm{O}_{1.8}$ sample showed $90 \%$ methane conversion at $680^{\circ} \mathrm{C}$ while $630^{\circ} \mathrm{C}$ for $\mathrm{Ce}_{0.1} \mathrm{Mg}_{0.9} \mathrm{O}_{1.1}$ (Chen et al., 2005b).

More chemical species, such as $\mathrm{Ba}, \mathrm{Zn}, \mathrm{Sn}, \mathrm{Ni}$, were added into CeZr mixed oxides (Chen et al., 2005a; Grisdanurak et al., 2007). Doping resulted in particle nanosize of $10-20 \mathrm{~nm}$ in diameter. $\mathrm{CeZrSn}_{0.5}$ showed the best performance on $\mathrm{CO}$ oxidation with a light-off temperature region of $175-210^{\circ} \mathrm{C}$. On the other hand, $\mathrm{NiO}$ enhanced the activity of partial oxidation of methane, when it was mixed into $\mathrm{Ce}_{0.75} \mathrm{Zr}_{0.25} \mathrm{O}_{2}$ powder. Approximately, $60 \%$ conversion of methane was observed at $700^{\circ} \mathrm{C}$ with good $\mathrm{H}_{2} / \mathrm{CO}$ ratio (Chen et al., 2005b).

The aim of this work was to study the influence of small addition of $\mathrm{Ni}$ metal to $\mathrm{CeMg}$ mixed oxide for $\mathrm{CO}$ oxidation reaction. The nanoparticle of catalyst was synthesized by macromolecule surfactant modified method in order to obtain high surface area catalyst. Furthermore, characterizations and catalytic activities on $\mathrm{CO}$ oxidation were also included.

\section{Experimental}

\subsection{Catalyst preparation}

Nanoparticles of $\mathrm{CeMgO}$ and $\mathrm{CeMgNiO}$ were prepared by macromolecule surfactant modified method. A solution of $\mathrm{Ce}\left(\mathrm{NO}_{3}\right)_{3} \cdot n \mathrm{H}_{2} \mathrm{O}, \mathrm{Mg}\left(\mathrm{NO}_{3}\right)_{2} \cdot n \mathrm{H}_{2} \mathrm{O}$ and 


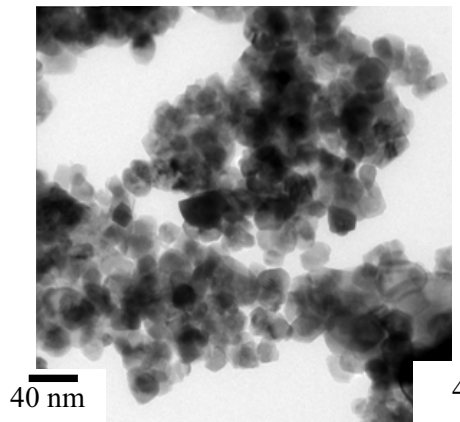

(a)

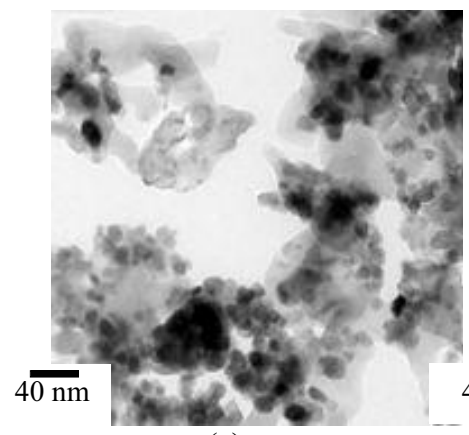

(c)

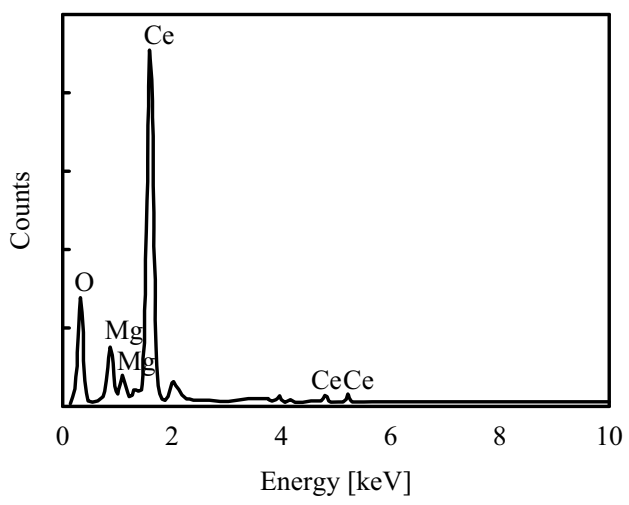

(e)

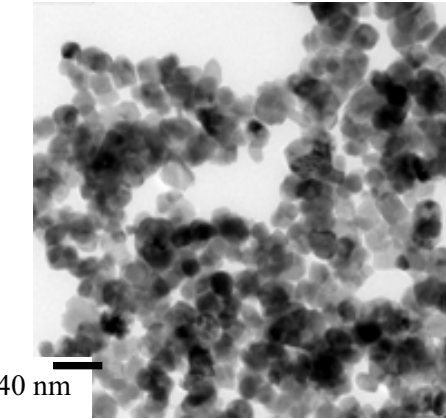

(b)

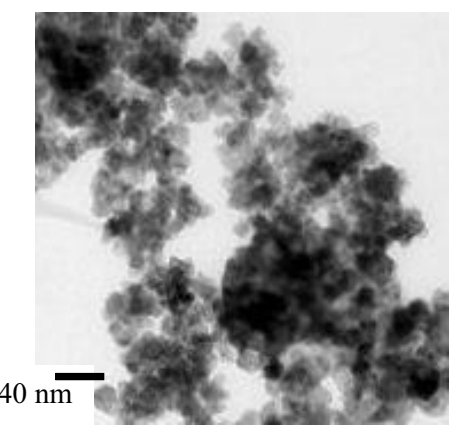

(d)

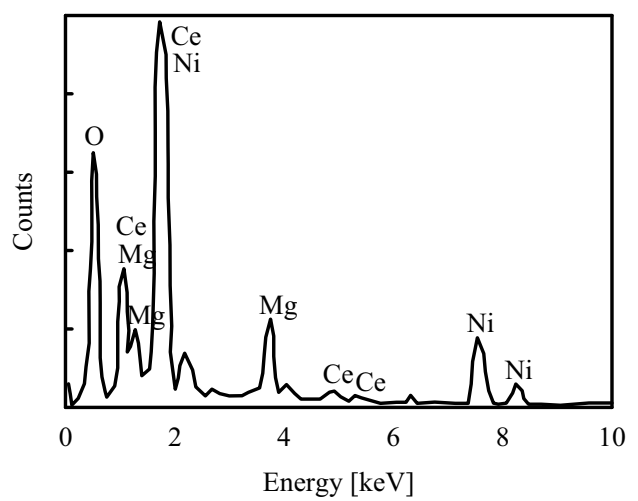

(f)

Fig. 1 TEM images of $\mathrm{CeMgO}$ and $\mathrm{CeMgNiO}$ samples with different $\mathrm{Ce} / \mathrm{Mg}$ ratios: (a) $\mathrm{Ce}_{0.9} \mathrm{Mg}_{0.1} \mathrm{O}_{2}$, (b) $\mathrm{Ce}_{0.5} \mathrm{Mg}_{0.5} \mathrm{O}_{2}$, (c) $\mathrm{Ce}_{0.1} \mathrm{Mg}_{0.9} \mathrm{O}_{2}$, (d) $\mathrm{Ce}_{0.1} \mathrm{Mg}_{0.9}-\mathrm{NiO}$, and EDX image of (e) $\mathrm{Ce}_{0.1} \mathrm{Mg}_{0.9} \mathrm{O}_{2}$ and (f) $\mathrm{Ce}_{0.1} \mathrm{Mg}_{0.9}-\mathrm{NiO}$

$\mathrm{Ni}\left(\mathrm{NO}_{3}\right)_{2} \cdot n \mathrm{H}_{2} \mathrm{O}$ was, respectively, mixed by a given amount, which was dependent on the designed composition of the mixed oxide. The mixed solution was added with a $5 \mathrm{wt} \%$ polyethylene glycol-20,000 following with stirring at room temperature. Then, solution $\mathrm{pH}$ was adjusted to 9 by $\mathrm{NH}_{4} \mathrm{OH}$ solution. The gel was placed below $0^{\circ} \mathrm{C}$ overnight, then, filtrated and added with $n$-butyl alcohol to azeotropic distillation with the precursors. After washing, the sample was calcined at $650^{\circ} \mathrm{C}$ for $4 \mathrm{~h}$ in air.

\subsection{Catalyst characterization}

The structure of mixed oxides was examined by $\mathrm{X}$ ray diffraction (XRD), a D/max-IIIB (Rigaku Corp.), using $\mathrm{Cu} \mathrm{K} \alpha$ radiation and a power of $40 \mathrm{kV} \times 40 \mathrm{~mA}$. Diffraction peaks were recorded at the $2 \theta$ between 20 $80^{\circ}$. The BET surface area of each catalyst was determined by means of physisorption, using a quantachrome NOVA automated gas sorption instrument. Prior to the analysis, the samples were outgassed at $350^{\circ} \mathrm{C}$ for $6 \mathrm{~h}$. The morphology of the samples was investigated by a transmission electron microscope-energy dispersion analysis X-ray (TEM-EDX), using a JEM-2010 (JEOL Ltd.) in which lanthanum hexaboride $\left(\mathrm{LaB}_{6}\right)$ was used as a filament.

\subsection{Catalyst activity measurement}

Catalytic oxidation of $\mathrm{CO}$ on mixed oxide catalysts was carried out in a fixed bed reactor mounted in the constant temperature $\left( \pm 1^{\circ} \mathrm{C}\right)$ zone of an electric furnace. A mixed oxide sample of $100 \mathrm{mg}$ was packed between two 


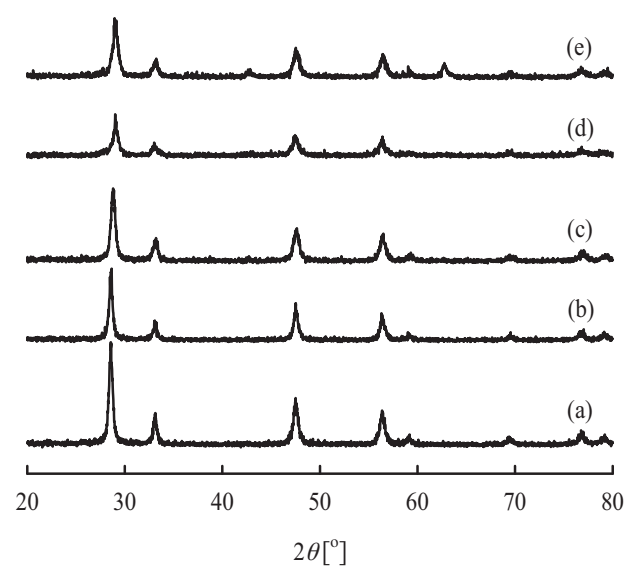

Fig. 2 XRD patterns of $\mathrm{CeMgO}$ and $\mathrm{CeMgNiO}$ samples with different $\mathrm{Ce} / \mathrm{Mg}$ ratios: (a) $\mathrm{CeO}_{2}$, (b) $\mathrm{Ce}_{0.9} \mathrm{Mg}_{0.1} \mathrm{O}_{2}, \quad$ (c) $\mathrm{Ce}_{0.5} \mathrm{Mg}_{0.5} \mathrm{O}_{2}, \quad$ (d) $\mathrm{Ce}_{0.1} \mathrm{Mg}_{0.9} \mathrm{O}_{2}$ and (e) $\mathrm{Ce}_{0.1} \mathrm{Mg}_{0.9}-\mathrm{NiO}$

layers of quartz wool inside a quartz tube (i.d. $=6 \mathrm{~mm}$ ) at atmospheric pressure. Small diameter thermocouple was located in the catalyst bed. The reaction temperature ranged from $120-380^{\circ} \mathrm{C}$ with a total feed gas flow rate of $50 \mathrm{~mL} / \mathrm{min}$, corresponding to a gas hourly space velocity (GHSV) of 30,000 $\mathrm{h}^{-1}$. The analysis of the effluents from the reactor was performed on line by a GC-8A (Shimadzu Corp.) equipped with Unibead $C$ packing columns and a TCD detector.

\section{Results and Discussion}

\subsection{Structural characters and the morphology anal- ysis}

To elucidate the effects of $\mathrm{CeMgNi}$ mixed oxide new material as a catalyst, the microstructure and threedimensional shape in particle size of $\mathrm{CeMgO}$ were examined by TEM. The average value of the crystallite size of the synthesized $\mathrm{CeMgO}$ new material was around 11$18 \mathrm{~nm}$, as shown in Figures 1(a)-(c). A doping of $\mathrm{Ni}$ onto CeMg mixed oxides (Figure 1(d)) does not affect its particle size and distribution significantly, compared to $\mathrm{CeMgO}$ itself (Figure 1(c)). The particles showed an equality distribution without agglomeration both before and after adding Ni metal into the mixed oxide catalyst. In this image, essentially each particle showed a smooth surface. The EDX chemical analysis, in Figures 1(e)-(f), clearly confirms the presence of $\mathrm{Ce}, \mathrm{Mg}$ and $\mathrm{Ni}$ on studied catalysts.

Figure 2 shows the XRD patterns of $\mathrm{CeO}_{2}, \mathrm{CeMgO}$ and $\mathrm{CeMgNiO}$ materials with different $\mathrm{Ce} / \mathrm{Mg}$ ratio. It can be seen clearly that the characteristic peaks of fluorite type of $\mathrm{CeO}_{2}$ can be detected on each $\mathrm{CeMgO}$ sample, which was located, respectively, on 28.56, 33.14, 47.5 and $56.36^{\circ}$ in $2 \theta$. There were no peaks due to crystal lines for magnesium phase or any other oxide compounds as also presented elsewhere (Chen et al., 2005b; Shan et
Table 1 BET surface areas of $\mathrm{CeMgO}$ with different $\mathrm{Ce} / \mathrm{Mg}$ ratios and $\mathrm{CeMgNiO}$

\begin{tabular}{lc}
\hline Catalysts & BET surface area $\left[\mathrm{m}^{2} / \mathrm{g}\right]$ \\
\hline $\mathrm{CeO}_{2}$ & 43.72 \\
$\mathrm{Ce}_{0.9} \mathrm{Mg}_{0.1} \mathrm{O}_{2}$ & 47.55 \\
$\mathrm{Ce}_{0.5} \mathrm{Mg}_{0.5} \mathrm{O}_{2}$ & 55.87 \\
$\mathrm{Ce}_{0.1} \mathrm{Mg}_{0.9} \mathrm{O}_{2}$ & 78.24 \\
$\mathrm{Ce}_{0.1} \mathrm{Mg}_{0.9}-\mathrm{NiO}$ & 25.21 \\
\hline
\end{tabular}

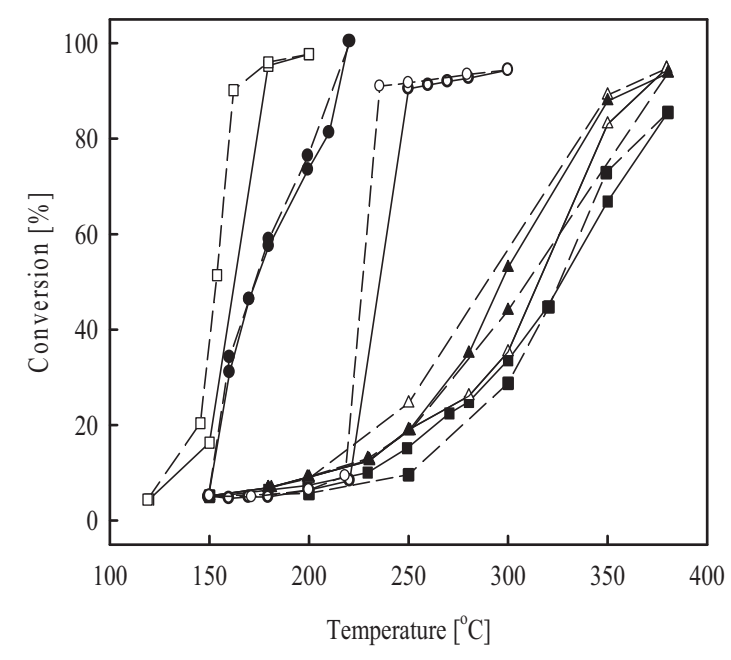

Fig. 3 CO oxidation activity over $\mathrm{CeMgM}$ mixed oxides catalysts; $\quad(\bigcirc) \quad \mathrm{CeO}_{2}, \quad(\boldsymbol{\Delta}) \mathrm{Ce}_{0.9} \mathrm{Mg}_{0.1} \mathrm{O}_{2}$, (ם) $\mathrm{Ce}_{0.5} \mathrm{Mg}_{0.5} \mathrm{O}_{2}, \quad(\triangle) \quad \mathrm{Ce}_{0.1} \mathrm{Mg}_{0.9} \mathrm{O}_{2}$, $(\diamond) \mathrm{Ce}_{0.1} \mathrm{Mg}_{0.9}-\mathrm{NiO}$, and $(\bigcirc) \mathrm{CeNiO}$ (solid lines: run-up; dash lines: run-down)

al., 2006). The generated fluorite type of $\mathrm{CeO}_{2}$ suggested that insertion of $\mathrm{Mg}^{2+}$ in the lattice of $\mathrm{CeO}_{2}$ could form a solid solution and maintain the cubic-fluorite structure. It was also found periclase structure of solid solution of $\mathrm{NiO}-\mathrm{MgO}$, located on $44.5,62.7^{\circ}$ in $2 \theta$ (Daza et al., 2008).

Apart from the homogeneity of the macromolecule surfactant modified method also possesses high surface area. The BET surface area of mixed oxide catalysts are summarized in Table 1. The results suggested that the stability of the surface areas of the catalysts increased with increasing the content of magnesium. It was found that the surface areas of the mixed oxides were higher than the surface area of pure ceria. This might be due to the fact that the crystallite growth process was retarded or disfavored by the incorporation of magnesium ions into the $\mathrm{CeO}_{2}$ matrix enhancing the thermal stability of the mixed oxide catalysts.

However, with doping nickel ion, the surface area of oxide sample was found to be decreased drastically. This might be caused by the migration of $\mathrm{Ni}$ species which can be dissolved into $\mathrm{Ce}-\mathrm{Mg}-\mathrm{O}$ like solid solution, as 
confirmed by XRD pattern.

\subsection{Catalytic activities of $\mathrm{CO}$ oxidation}

The study was focused on the oxidation of $\mathrm{CO}$ over the mixed oxide catalysts: $\mathrm{CeO}_{2}, \mathrm{CeMg}$ mixed oxide (Ce/Mg ratio: $1 / 9,5 / 5$ and 9/1), $\mathrm{Ce}_{0.1} \mathrm{Mg}_{0.9}-\mathrm{NiO}$ and $\mathrm{CeNiO}$, as shown in Figure 3. It demonstrates light-off curves of $\mathrm{CO}$ oxidation activity for all catalysts. The catalytic activity of mixed oxide catalysts increased with increasing reaction temperature for all samples. The $\mathrm{CO}$ oxidation activities of all ratios of $\mathrm{Ce} / \mathrm{Mg}$ were quite similar to that of $T_{80}$ (temperature for $80 \%$ conversion) of $\mathrm{Ce} / \mathrm{Mg}$ ratio of $1 / 9,5 / 5$ and $9 / 1$ were at 350,370 and $350^{\circ} \mathrm{C}$, respectively and were much higher than that of $\mathrm{CeO}_{2}\left(T_{80}\right.$ was $\left.250^{\circ} \mathrm{C}\right)$. Considering only $\mathrm{Mg}$ on $\mathrm{CeO}_{2}$, it should be pointed out that an addition of $\mathrm{Mg}$ had no influence on $\mathrm{CO}$ oxidation.

Considering the catalytic activity based on $T_{80}$ of $\mathrm{Ce}_{0.1} \mathrm{Mg}_{0.9}-\mathrm{NiO}, \mathrm{CeNiO}$, and $\mathrm{CeO}_{2}$, it was found to be 170,207 , and $244^{\circ} \mathrm{C}$, respectively. The best activity of $\mathrm{CO}$ oxidation was performed under catalyst obtained by the coprecipitation of $\mathrm{Ni}^{2+}, \mathrm{Mg}^{2+}$ and $\mathrm{Ce}^{2+}$. As a result, addition of nickel and magnesium into Ce mixed oxide was beneficial for higher reducibility of catalyst (Daza et al., 2008).

Combined with XRD and BET results, the typical structure in $\mathrm{Ce}_{0.1} \mathrm{Mg}_{0.9}-\mathrm{NiO}$ contains the active sites for low temperature $\mathrm{CO}$ oxidation and the catalytic activity has no direct correlation with surface areas, which was similar to results presented by Thammachart et al. (2001).

\section{Conclusion}

$\mathrm{CeMg}$ mixed oxide nanomaterial and doping with $\mathrm{Ni}$ metal was obtained by a macromolecule surfactant modified method. The catalysts were characterized for their crystalline structure, particle sizes, and surface area. The synthesis method resulted in the formation of solid solution of cubic fluorite, and periclase crystalline phase, moderate surface area and particle size smaller than $20 \mathrm{~nm}$. $\mathrm{Ce}_{0.1} \mathrm{Mg}_{0.9}-\mathrm{NiO}$ solid solution was reported to have the highest activity among mixed oxide catalysts. It was probably reasonable that the high reducibility was more effective in $\mathrm{CO}$ oxidation activity than the high surface area of catalysts.

\section{Acknowledgments}

This work is partially supported by Thailand Graduate Institute of Science and Technology, TGIST (2007).

\section{Literature Cited}

Boaro, M., M. Vicario, C. de Leitenburg, G. Dolcetti and A. Trovarelli; "The Use of Temperature-Programmed and Dynamic/Transient Methods in Catalysis: Characterization of Ceria-Based, Model Three-Way Catalysts," Catal. Today, 77, 407-417 (2003)

Chen, M., Y. H. Zhu and X. M. Zheng; "A Novel Material of $\mathrm{Ce}_{0.7} \mathrm{Zr}_{0.3} \mathrm{Ba}_{0.1} \mathrm{O}_{2.1}$ : Synthesis, Characterization and Its Catalytic Performance for CO Oxidation," Mater. Chem. Phys., 92, 43-47 (2005a)

Chen, M., H. Zheng, C. Shi, R. Zhou and X. Zheng; "Synthesis of Nanoparticle Ce-Mg-O Mixed Oxide as Efficient Support for Methane Oxidation,' J. Mol. Catal. A, 237, 132-136 (2005b)

Costa, C. N., S. Y. Christou, G. Georgiou and A. M. Efstathiou; "Mathematical Modeling of the Oxygen Storage Capacity Phenomenon Studied by $\mathrm{CO}$ Pulse Transient Experiments over $\mathrm{Pd} / \mathrm{CeO}_{2}$ Catalyst," J. Catal., 219, 259-272 (2003)

Daza, C. E., J. Gallego, J. A. Moreno, F. Mondragón, S. Moreno and R. Molina; " $\mathrm{CO}_{2}$ Reforming of Methane over Ni/Mg/Al/Ce Mixed Oxides," Catal. Today, 133-135, 357-366 (2008)

Grisdanurak, N., P. Phatai and A. Neramittagapong; "Characteristics and Performance of $M$-Doping Cerium Zirconium Mixed Oxide Nanosized Catalysts ( $M=\mathrm{Zn}, \mathrm{Sn})$ in CO Oxidation," React. Kinet. Catal. Lett., 92, 213-221 (2007)

Kasaepar, J., P. Fornasiero and M. Graziani; "Use of $\mathrm{CeO}_{2}$-Based Oxides in the Three-Way Catalysis," Catal. Today, 50, 285-298 (1999)

Li, M., D. H. Wang, X. C. Shi, Z. T. Zhang and T. X. Dong; "Kinetics of Catalytic Oxidation of CO over Copper-Manganese Oxide Catalyst," Sep. Purif. Technol., 57, 147-151 (2007)

Ma, Z., S. Brown, S. H. Overbury and S. Dai; "Au/PO ${ }_{4}^{3-} / \mathrm{TiO}_{2}$ and $\mathrm{PO}_{4}^{3-} / \mathrm{Au} / \mathrm{TiO}_{2}$ Catalysts for CO Oxidation: Effect of Synthesis Details on Catalytic Performance," Appl. Catal., A, 327, 226-237 (2007)

Over, H. and M. Muhler; "Catalytic CO Oxidation over RutheniumBridging the Pressure Gap," Prog. Surf. Sci., 72, 3-17 (2003)

Romero-Sarria, S. F., J. C. Vargas, A. C. Roger and A. Kiennemann; "Hydrogen Production by Steam Reforming of Ethanol: Study of Mixed Oxide Catalysts $\mathrm{Ce}_{2} \mathrm{Zr}_{1.5} \mathrm{Me}_{0.5} \mathrm{O}_{8}$ : Comparison of $\mathrm{Ni} / \mathrm{Co}$ and Effect of Rh," Catal. Today, 133-135, 149-153 (2008)

Shan, W., M. Fleys, F. Lapicque, D. Swierczynski, A. Kiennemann, Y. Simon and P. M. Marquaire; "Syngas Production from Partial Oxidation of Methane over $\mathrm{Ce}_{1-X} \mathrm{Ni}_{X} \mathrm{O}_{Y}$ Catalysts Prepared by Complexation-Combustion Method," Appl. Catal., A, 311, 24-33 (2006)

Terribile, D., A. Trovarelli, J. Llorca, C. de Leitenburg and G. Dolcetti; "The Preparation of High Surface Area $\mathrm{CeO}_{2}-\mathrm{ZrO}_{2}$ Mixed Oxides by a Surfactant-Assisted Approach," Catal. Today, 43, 79-88 (1998)

Thammachart, M., V. Meeyoo, T. Risksomboon and S. Osuwan; "Catalytic Activity of $\mathrm{CeO}_{2}-\mathrm{ZrO}_{2}$ Mixed Oxide Catalysts Prepared via Sol-Gel Technique: CO Oxidation,' Catal. Today, 68, 53-61 (2001)

Zhang, Y., Z. Li, X. Wen and Y. Liu; "Partial Oxidation of Methane over Ni/Ce-Ti-O Catalysts," Chem. Eng. J., 121, 115-123 (2006)

Zhu, H., Z. Qin, W. Shan, W. Shen and J. Wang; "CO Oxidation at Low Temperature over Pd Supported on $\mathrm{CeO}_{2}-\mathrm{TiO}_{2}$ Composite Oxide," Catal. Today, 126, 382-386 (2007) 